\title{
PENANAMAN TANAMAN OBAT KELUARGA (TOGA) UNTUK MENINGKATKAN IMUNITAS TUBUH SEBAGAI PENCEGAHAN COVID-19
}

\author{
Sunawan*, Firli Puspa Amalia, Widiya Wulandari, Nency Priskila Oktaviani \\ Fakultas Pertanian, Universitas Islam Malang \\ *korespondensi email: sunawan@unisma.ac.id
}

\begin{abstract}
ABSTRAK
TOGA adalah tanaman yang tidak memerlukan perawatan khusus, tidak mudah diserang hama penyakit, bibitnya mudah didapat, mudah tumbuh dan tidak termasuk jenis tanaman terlarang dan berbahaya atau beracun. Tanaman obat banyak digunakan sebagai bahan baku obat tradisional dan jamu, yang apabila dikonsumsi dapat meningkatkan kekebalan tubuh (immune system). Tujuan dari kegiatan KSM Tematik 2021 UNISMA adalah memanfaatkan lahan untuk ditanamani TOGA dalam jangka panjang dengan memnfaatkan hasil panen dari TOGA tersebut guna meningkatkan kesehatan dan perekonomian masyarakat setempat di era pandemi COVID-19. Metode pelaksanaan yang dilakukan dalam program taman Tanaman Obat Keluarga (TOGA) ini terbagi menjadi tiga tahapan yaitu persiapan, pelaksanaan, dan evaluasi kegiatan. Masyarakat menyediakan lahan untuk ditanami TOGA dan menerima dengan baik terkait program kerja mahasiswa.
\end{abstract}

Kata Kunci: TOGA; imunitas; covid-19

\section{PENDAHULUAN}

COVID-19 (Coronavirus Disease 2019) merupakan penyakit pada gangguan pernapasan (pneumonia) yang pertama kali ditemukan di kota Wuhan Tiongkok dan diumumkan secara resmi oleh WHO (World Health Organization) pada akhir Desember 2019. Penyebaran yang sangat cepat membuat WHO menyatakan situasi menjadi pandemi kronis pada tanggal 11 Maret 2020.

Menurut Pertiwi et al. (2020) pandemi adalah wabah global dari virus baru. Pandemi terjadi ketika virus baru muncul yang dapat menginfeksi manusia dan menyebar dari manusia ke manusia dengan cara yang cepat dan berkelanjutan. Sangat sedikit manusia yang memiliki kekebalan terhadap virus pandemi karena itu baru bagi manusia, dan vaksin mungkin tidak tersedia secara luas. Sejauh ini, belum ditemukannya obat spesifik yang dapat digunakan untuk menyembuhkan penderita yang terinfeksi COVID-19. Terapi yang digunakan hanyalah untuk menghilangkan gejala yang muncul dan meningkatkan imunitas penderita agar kuat melawan virus tersebut. Pemerintah juga menghimbau seluruh masyarakat untuk meningkatkan imunitas tubuh agar terhindar dari infeksi COVID-19. Imunitas tubuh dapat ditingkatkan dengan menerapkan perilaku pola hidup sehat.

Peningkatan imunitas dapat dilakukan dengan menggunakan berbagai ramuan tradisional yang dikenal dengan istilah jamu. Potensi peningkatan imunitas dari olahan jamu dapat diperoleh dari tanaman obat keluarga atau yang dikenal dengan istilah TOGA. Dalam bidang tanaman obat, Indonesia dikenal sebagai salah satu negara yang memiliki keanekaragaman hayati terbesar kedua setelah Brazil, sehingga sangat potensial dalam 
mengembangkan tanaman obat yang berbasis pada tanaman obat kita sendiri. Indonesia kaya akan aneka ragam tanaman obat. Lebih dari 1000 spesies tumbuhan dapat dimanfaatkan sebagai bahan baku obat, oleh karena itu budidaya tanaman obat di Indonesia memiliki potensi yang sangat baik untuk dikembangkan (Nugraha \& Agustiningsih, 2015).

Pemanfaatan tanaman obat keluarga (TOGA) yang lebih alami oleh masyarakat Indonesia, secara turuntemurun sebagai warisan budaya bangsa. Tanaman obat tradisional digunakan dan dilaporkan secara empirik oleh masyarakat bermanfaat meningkatkan kesehatan dan pengobatan berbagai penyakit (Karo-karo, 2010).

Tanaman obat keluarga pada hakekatnya sebidang tanah baik di halaman rumah, kebun ataupun ladang yang digunakan untuk membudidayakan tanaman yang berkhasiat sebagai obat dalam rangka memenuhi keperluan keluarga akan obat-obatan. Bagian tanaman yang dapat dimanfaatkan sebagai obat yaitu bagian daun, kulit batang, buah, biji, bahkan bagian akarnya (Karamina et al., 2020; Rachmasari et al., 2021). Jenis tanaman yang dibudidayakan sebagai TOGA adalah tanaman yang tidak memerlukan perawatan khusus, tidak mudah diserang hama penyakit, bibitnya mudah didapat, mudah tumbuh dan tidak termasuk jenis tanaman terlarang dan berbahaya atau beracun. Pemanfaatan tanaman TOGA tersebut dapat mengatasi masalah-masalah kesehatan. Hal ini menunjukkan bahwa obat yang berhasil dari sumber bahan alam khususnya tanaman telah memperlihatkan perannya dalam penyelenggaraan upaya-upaya kesehatan.

Dalam aspek pemeliharaan kesehatan TOGA yang berperan sebagai obat tradisional banyak digunakan sebagai upaya pencegahan. (Upaya preventif). Pemanfaatan Tanaman obat keluarga (TOGA) merupakan tradisi masyarakat dalam kehidupan sehari-hari, dimana pemanfaatan tanaman obat sebagai bahan pengobatan penyakit telah berakar kuat di tengah-tengah kehidupan masyarakat, terutama masyarakat yang tinggal di desa (Harefa, 2020). Meskipun saat ini perkembangan teknologi semakin maju penggunaan TOGA tetap diminati masyarakat, hal ini dapat dilihat dari banyaknya inovasi pengolahan obat-obatan tradisional secara mandiri.

Salah satu program kerja KSM-Tematik kelompok 92 Universitas Islam Malang dalam KKN edisi Covid-19 ini yaitu penanaman Tanaman Obat Keluarga (TOGA) di Desa Tlekung, Kecamatan Junrejo, Kota Batu. Tanaman obat banyak digunakan sebagai bahan baku obat tradisional dan jamu, yang apabila dikonsumsi dapat meningkatkan kekebalan tubuh (immune system), karena tanaman ini mempunyai sifat spesifik sebagai tanaman obat yang bersifat pencegahan (preventif) dan promotif melalui kandungan metabolit sekunder contohnya seperti gingiro pada jahe dan santoriso pada temulawak yang mampu meningkatkan sistem kekebalan tubuh.

Berdasarkan latar belakang diatas perlu dilakukannya kegiatan untuk memberikan pengetahuan dan produk hasil tanaman TOGA. Hal ini didukung dengan Pekarangan warga yang tidak dimanfaatkan dan telah ditumbuhi beberapa gulma. Hasil dari kegiatan ini diharapkan dapat meningkatkan kesadaran mahasiswa dan masyarakat untuk meningkatkan daya tahan tubuh untuk menjaga kualitas kesehatan dengan menkonsumsi jamu dari TOGA di pekarangan sekitar.

\section{METODE}

Kegiatan pengabdian masyarakat ini dilakukan serangkaian dengan kegiatan KSMTematik Berbasis Keilmuan dan Domisili Edisi Covid-19. Pelaksanaan kegiatan ini dilaksanakan di desa masing-masing selama satu bulan. Alat dan bahan yang digunakan yaitu cangkul, sabit, parang, cetok, polybag, bibit tanaman TOGA (kunyit, temuireng, laos, serai, lidah buaya, insulin, jahe, kangkung). Metode pelaksanaan yang dilakukan yaitu sosialisasi 
secara langsung. Di mana dalam pelaksanaannya terdapat beberapa tahapan, yaitu: tahap persiapan, tahap pelaksanaan, dan tahap evaluasi kegiatan.

1. Tahap Persiapan

Pada tahap ini hal yang dilakukan pertama yaitu melakukan survei lahan dan koordinasi dengan Ketua RW setempat terkait pelaksanaan kegiatan penanaman tanaman TOGA.

2. Tahap Pelaksanaan

Pada tahap ini mahasiswa melakukan mulai dari sanitasi lahan, mempersiapkan media tanam, menanam tanaman TOGA di polybag, dan menata tanaman di lahan TOGA.

3. Tahap Evaluasi Kegiatan

Setelah selesai melakukan kegiatan pelaksanaan, masyarakat akan bisa melihat perkembangan dari tanaman TOGA.

\section{HASIL DAN PEMBAHASAN}

Kegiatan tahap pertama yaitu pemaparan rancangan program taman Tanaman Obat Keluarga (TOGA) kepada Ketua RT, RW, dan kelompok tani setempat sebagai upaya optimalisasi lahan dan meningkatkan imun tubuh masyarakat.

Tahap kedua dimulai dari mempersiapkan dan membersihkan lahan terlebih dahulu. Kemudian membuat media tanam di polybag dengan menggunakan tanah yang di campur, pupuk kandang, dan sekam padi. Perbandingan antara tanah, pupuk kandang, dan sekam padi yaitu 1:1:1. Setelah itu bibit ditanam kedalam lubang taman sedalam $5 \mathrm{~cm}$ dan ditutup tanah kembali. Untuk perawatan tanaman TOGA disiram sebanyak dua kali sehari dengan kapasitas tanah hingga lebih basah. Untuk penangangan gulma bisa dilakukan seminggu sekali. Selain itu dipasang pasak dan banner pada bagian depan taman guna mempermudah masyarakat mengetahui taman tersebut.

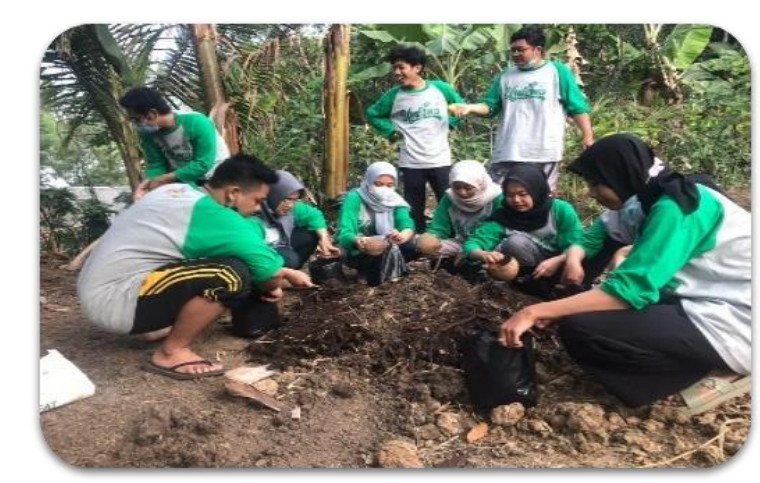

Gambar 1. Pengambilan media tanah

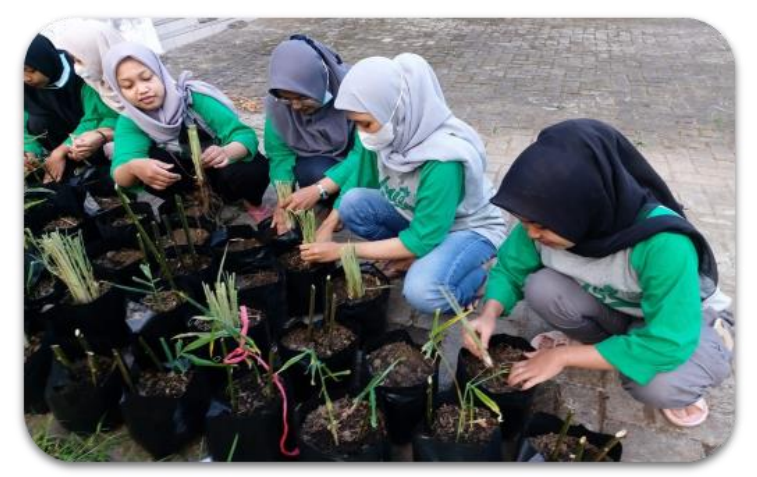

Gambar 2. Persiapan bibit toga 
Tahap ke tiga melakukan monitoring baik online maupun offline atas perkembangan taman TOGA dengan memberikan edukasi pengolahan hasil panen untuk kesehatan atau bahkan dijadikan produk seperti jamu, minuman kesehatan, bumbu masakan dan lain-lain untuk diperjualkan sebagai pemasukan perekonomian di masa pandemi. Sehingga lahan bisa dimanfaatkan dengan baik serta dapat meningkatkan kesehatan masyarakat di era pandemi covid-19.

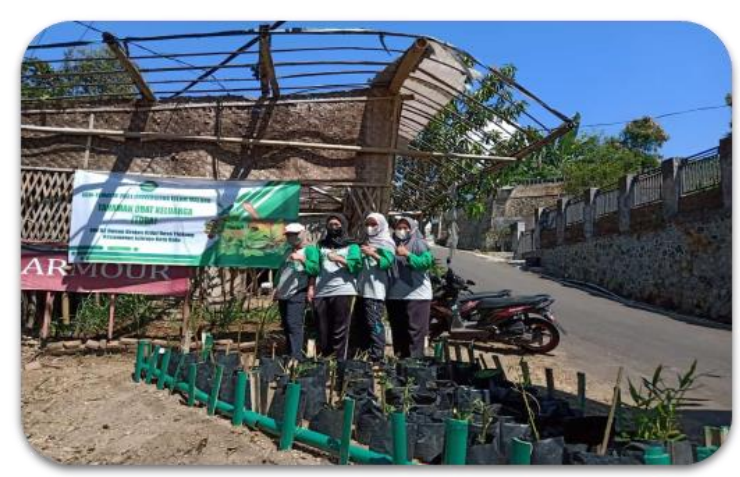

Gambar 3. Monitoring perkembangan taman TOGA

\section{KESIMPULAN}

Masyarakat menyediakan lahan untuk ditanami TOGA dan menerima dengan baik terkait program kerja mahasiswa. Dengan penanaman TOGA ini, diharapkan dapat memberikan manfaat bagi masyarakat di era pandemi covid-19 dan dapat mengedukasi masyarakat tentang penanaman dan pemanfaatan lahan untuk ditanami TOGA berjalan sesuai rencana.

\section{DAFTAR RUJUKAN}

Harefa, D. (2020). Pemanfaatan Hasil Tanaman Sebagai Tanaman Obat Keluarga (TOGA). Madani : Indonesian Journal of Civil Society, 2(2), 28-36. https://doi.org/10.35970/madani.v1i1.233

Karamina, H., Supriyadi, S., Firman Yasin, D. D., Yusi Kamhar, M., \& Kusuma Astuti, F. (2020). Pemanfaatan dan Penanaman Tanaman Obat Keluarga (TOGA) Menuju Keluarga Sehat Pada Ibu Pemberdayaan Kesejahteraan Keluarga (PKK). Jurnal Inovasi Hasil Pengabdian Masyarakat (JIPEMAS), 3(2), 120-127. https://doi.org/10.33474/jipemas.v3i2.6416

Karo-karo, U. (2010). Pemanfaatan Tanaman Obat Keluarga di Kelurahan Tanah 600 , Medan. KESMAS, Jurnal Kesehatan Masyarakat Nasional, 4(5), 195-202. https://doi.org/10.21109/kesmas.v4i5.169 Refbacks

Nugraha, S. P., \& Agustiningsih, W. R. (2015). Pelatihan Penanaman Tanaman Obat Keluarga (TOGA). Asian Journal of Innovation and Entrepreneurship (AJIE), 4(1), 58-62. https://journal.uii.ac.id/ajie/article/view/7896

Pertiwi, R., Notriawan, D., \& Wibowo, R. H. (2020). Pemanfaatan Tanaman Obat Keluarga (TOGA) Meningkatkan Imunitas Tubuh sebagai Pencegahan Covid-19. Dharma Raflesia : Jurnal Ilmiah Pengembangan Dan Penerapan IPTEKS, 18(2), 110-118. https://doi.org/10.33369/dr.v18i2.12665

Rachmasari, R. P. W., Simanjuntak, R., Kusnadi, Arkadius, D., \& Gustianta, E. (2021). Penanaman dan Pemanfaatan Budi Daya Tanaman Toga di Pekarangan Rumah guna Meningkatkan Pemberdayaan Kesehatan Keluarga. Research Lembaran Publikasi Ilmiah, 4(2), 1-6. https://doi.org/10.35439/research.v4i2.37 